\title{
Implementing E-learning Training toward English Virtual Lecturers: The Process, Perspectives, Challenges and Solutions
}

\author{
https://doi.org/10.3991/ijet.v16i04.14125 \\ Eka Apriani ${ }^{(凶)}$ \\ Institut Agama Islam Negeri (IAIN) Curup, Bengkulu, Indonesia \\ eka.aprianieiaincurup.ac.id \\ Syafryadin \\ Universitas Bengkulu, Bengkulu, Indonesia \\ Rita Inderawati \\ Universitas Sriwijaya, Palembang, Indonesia \\ Arin Arianti \\ Universitas Veteran Bangun Nusantara Sukoharjo, \\ Jawa Tengah, Indonesia \\ Sakdiah Wati \\ Universitas Muhammadiyah Palembang, Palembang, Indonesia \\ Ihsan Nul Hakim \\ Institut Agama Islam Negeri (IAIN) Curup, Bengkulu, Indonesia \\ Noermanzah \\ University of Bengkulu, Bengkulu, Indonesia
}

\begin{abstract}
This study explored the e-learning training implementation which covered the lecturers' perspective, the barriers, and its solution. The research population was 50 postgraduate lecturers; however, only 9 English education postgraduate lecturers joined this training. The research design of this study was qualitative research which applied observation checklist, interview, and notetaking as the instruments to collect the data. The data analysis of this study used a qualitative method which comprised several steps i.e., collecting, coding, organizing, and interpreting the data. The findings showed that the implementation of e-learning has been done by the trainer and the lecturers followed it. However, the problems that occurred during the implementation of this training were lack of discipline, poor material understanding, bad electricity, bad internet connection, unavailable modules of e-learning, and the old age of the participants. The trainer provided the assistant to help them in handling these issues. Another finding was that most of the lecturers had a positive perspective about e-learning training because this training could assist them in teaching.
\end{abstract}

Keywords-E-learning training, implementation, perspective, barriers, solution 


\section{Introduction}

In the digital era, most of the activities use some form of technology. Consequently, lecturers or teachers must engage with the technology in the teaching and learning process. Technology can be as media for lecturers or teachers to educate the students [1]. Besides. Information Technology and Communication (ICT) has the potential to create a conducive atmosphere for students to learn English. Moreover, e-learning is a medium that uses the internet to convey the information and enhance the knowledge of the user in learning. The lecturers need to know the development of technology in the teaching and learning process because technology has a function of helping the lecturers in teaching English [2]. Thus, lecturers can use sophisticated tools, such as in using technology and going virtual lecturers. The technology that will be implemented is elearning, where e-learning can be accessed by the students and the lecturers through computer and mobile. In the preliminary interview with several lecturers, the problems in terms of e-learning are (1) they seldom used e-learning due to the fact that they did not know how to use it and (2) they did not use e-learning because most of the lecturers are over 50 years. Hence, they believe that they do not need it. These problems must be followed up. The lecturers must learn how to be virtual lecturers by knowing the elearning. In the Postgraduate program of Bengkulu University, lecturers were obligated to use e-learning applications to teach students because most of the students in the postgraduate programs are from the countryside.

Several studies have already researched the use of ICT in the teaching and learning process. Those previous studies have similarities and differences. First, [3] and [4] only conducted the research on a literature review of using ICT in the teaching and learning process. Similarly, [5] and [6] conducted conceptual research on the use of ICT, for instance, Edmodo and Facebook in the teaching and learning process. Second, [7], [8], [9], [10] and [11] who conducted the research on the perception or belief of using ICT either from the students' view or teachers' view. The results of those studies showed that the students and the teachers had a positive response toward ICT utilization. Third, many researchers examined the use of ICT in the teaching learning process which affected on students' achievement [12]. [13], [14], [15], [16], [17], [18], [19], [20], [21], [22], [23], [24], [25], [26], [27]. However, several studies did not only examine the students' achievement, but also motivation, such as [13], [14], [18]. Besides, there was a study that compared the mobile-based learning and traditional learning process [19]. Also, [22] and [23] conducted the research which examined not only the use of ICT, but also the attitude, motivation, and academic achievement. Most of the studies used quantitative research. The results of those studies showed that ICT can be used to enhance the students' motivation and their learning achievement. Fourthly, [28] did research which focused on ICT and speaking, while [29] researched on ICT and grammar. [30] conducted the research which aimed to know how technology is integrated within the context of English teacher education programs and how do the teachers prepare teaching of technology and new literacies in the context of English language arts.

In short, most previous studies were about examining ICT in all skills in English, review of literature and conceptual research of ICT and students' perception or belief 
and motivation because of ICT integration in learning English. However, only two studies touted about ICT in learning grammar and speaking. Most of the previous studies were qualitative research. Therefore, the current research is distinct from previous studies, because the study explored E-learning training for English postgraduate lecturers in terms of process, perspectives, challenges and solution. The research questions of this present study were (1) How is the process of e-learning training for postgraduate lecturers? (2) What is the lecturers' perspective toward the implementation of the e-learning training? And (3) What are the challenges to the implementation of the e-learning training and its solution? These research questions were in line with the objectives of the present study. The significance of this research was for the trainer, postgraduate lecturers, and further researcher. For the trainer, this training could be one of the events which shared the knowledge. Thus, for the postgraduate lecturers, this training could be considered as a novel experience or a beneficial activity which helps them in the teaching and learning process. Besides, this training could make them a virtual lecturer which helps students in learning.

\section{$2 \quad$ Literature Review}

\subsection{Concept of e-learning}

E-learning as a media for teaching and learning process that helps the lecturer or teacher in enhancing the students' ability. Besides, e-learning is a system that uses a technology to be used in teaching and learning. Another definition of e-learning is a tool to support the teaching and learning process in long distance [2]. Furthermore, elearning refers to the teaching and learning process, which does not need a face-to-face interaction between the teacher and the students. The objectives of e-learning are:

1) To create the students to be independent learner

2) To enhance the quality of learning material

3) To improve the participation of the students

4) To stimulate the development of creativity and innovation of the students in learning.

E-learning has three functions namely: functioning as a supplement, a complement, and substitution. As a supplement, e-learning can be used by the students or the learners or participants as an additional material in the learning process. As a complement, elearning can be used to complete the material that students cannot get from the book. As substitution, e-learning can be used to substitute the teaching and learning process inside the classroom. E-learning has a principle that has a relation to the network that can easily be updated, saved, and distributed. Furthermore, e-learning has several advantages, for instance, the time is flexible for students, students will be more independent in learning, and students do not need to spend much money. This study applied e-learning in the Website of Bengkulu University. Thus, students, have to register at https://elearning.unib.ac.id/ before joining a course in e-learning. 


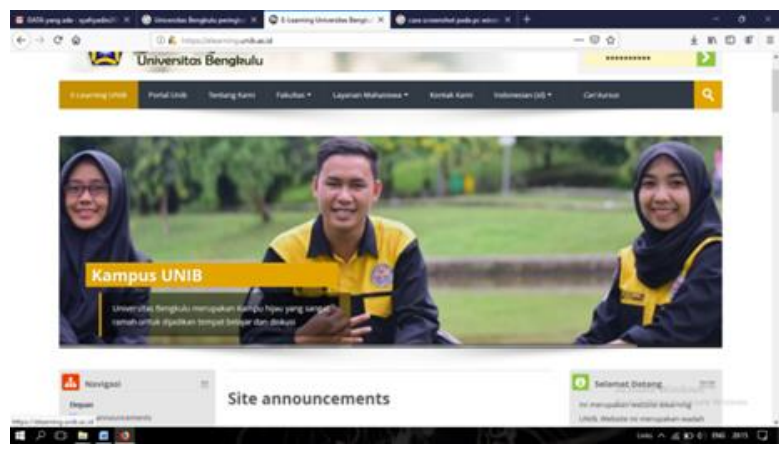

Fig. 1. E-learning unib

\subsection{Types of e-learning}

E-learning has two types, namely synchronous and asynchronous. The first, synchronous e-learning means that the students and the lecturers or the teachers interact online during the teaching and learning process at the same time. For example, the lecturer uploads the slides of the presentation in e-learning website or uploads the video presentation, at the same time the students are online to listen and see the presentation of the lecturer. If there is a question related to the presentation, the students can chat with the lecturer or the teacher by using a chat window. The second, asynchronous elearning refers to the online teaching and learning process while the students and the teachers are not necessarily connected online at the same time and where both students and lecturers avail themselves of web-based learning, which has proven beneficial for both parties alike [36]. In this case, the students can learn any time based on the schedule that has been decided by the lecturer or teacher. The learning system can be in the form of a task, a quiz, reading, and a test [2].

\subsection{Perspective of e-learning}

Perspective refers to the assumption or opinion about something. In this context, the perspective of e-learning is an opinion about the e-learning itself either for the implementation or the output. There are two kinds of perspectives, namely a positive and a negative perspective. [15] state that e-learning is one of the ICT products which gives a positive impact on the students. It is in line with [13] and [14] who also stated that students have a positive perception towards the implementation of ICT, given that it can help them in learning.

\subsection{The problems of e-learning and its solution}

E-learning has technical problems. According to [5], the problems of ICT, especially e-learning, are internet connection and the procedures of e-learning. The main problems of e-learning are materials, difficulty to understand, time management, and the quality 
of the trainer. The solution to these problems can be based on the trainer to explain more about the steps and to offer extra lessons.

\section{$3 \quad$ Research Methodology}

This study applied a descriptive qualitative to find information about the phenomenon. As [31] stated that qualitative research aimed to know how the participants experience and engage with the phenomenon that occurs. The population of this research was 50 postgraduate lecturers, but the sample of this research was 9 English postgraduate lecturers because the total postgraduate lecturers is 50 from all departments and the total number of English lecturers in education postgraduate program was only nine lecturers. This study used purposive sampling because most lecturers had low ability in using e-learning. The research instruments of this study were interview, note-taking and observation checklist. Those instruments had been validated by the expert judgments. The data were collected by using the instruments. The procedures of collecting the data were:

1) The researcher (observer) took note every meeting of the training

2) After the training of every meeting finished, the researcher filled the observation checklist

3) The researcher interviewed the trainer and the participants after the training in every meeting, so the researcher could detail know what was going on

The data analysis was done qualitatively, which is comprised of several steps, such as collecting data, coding it, doing reflection on it, organizing it, and interpreting it. First, gathering the data entailed the researcher taking from instruments. Second, the transcripts of interviews, note-taking, and the observation sheet were coded by the researcher based on the important information. Coding the instruments, the researcher highlighted the important aspects based on the initial research questions. Third, the researcher reflected on the data by a full screening including essential data in a file. Fourth, organizing the data, the researcher divided the data based on answering the research questions in order. After organizing the data, the next step was interpreting it. The researcher carefully and critically interpreted the data. Thus, the result of interpretation could be useful for answering the research questions. These data analyses were useful for the researcher to answer the research questions.

\section{$4 \quad$ Findings}

The findings of this study referred to the research questions namely: How is the process of e-learning training for postgraduate lecturers? (2) What is the lecturers' perspective toward the implementation of the e-learning training? And (3) What are the barriers of the implementation of the e-learning training and its solution? The findings could be illustrated as follows: 


\subsection{Process of e-learning training for postgraduate lecturers}

The process of e-learning training took 4 days of training because the trainer wanted to make sure all the lecturers understood e-learning. In the first meeting, the trainer introduced the training to all lecturers, who created an account to access the e-learning portal on the website of Bengkulu University. After all the lecturers had accounts and accessed the e-learning portal, the trainer taught the participants how to make a class on the website. It needed a long process because the participants had to follow the steps that the trainer showcased. In this first meeting, the participants had to copy their lesson plan or lesson scenario into the e-learning class, so that the students could access the lesson plan for one semester. During the second meeting, the participants filled the material every meeting in e-learning class. Every participant had to design creative materials. The participants could upload a video, picture, power point presentation, and other media. This process needed more time because the participants filled the material for 16 meetings. At the third meeting, the participants learned how to run a quiz, midtest and final-test on the e-learning platform. In this case, the participants provided the questions for the quiz, mid-test and final test. After that, the participants insert the questions in e-learning. Next, the participants set the time for the test. During the fourth meeting, the participants were trained on how to set up the assessment for the test. Besides, the participants also set up as the students so, the students could enter the elearning classroom. In short, the implementation of this e-learning training could run well even though there are some problems in implementation. The problems of the implementation were discussed in the part of the barriers of the application of the training. The steps of e-learning training could be illustrated in graph 2 and figures as follows.

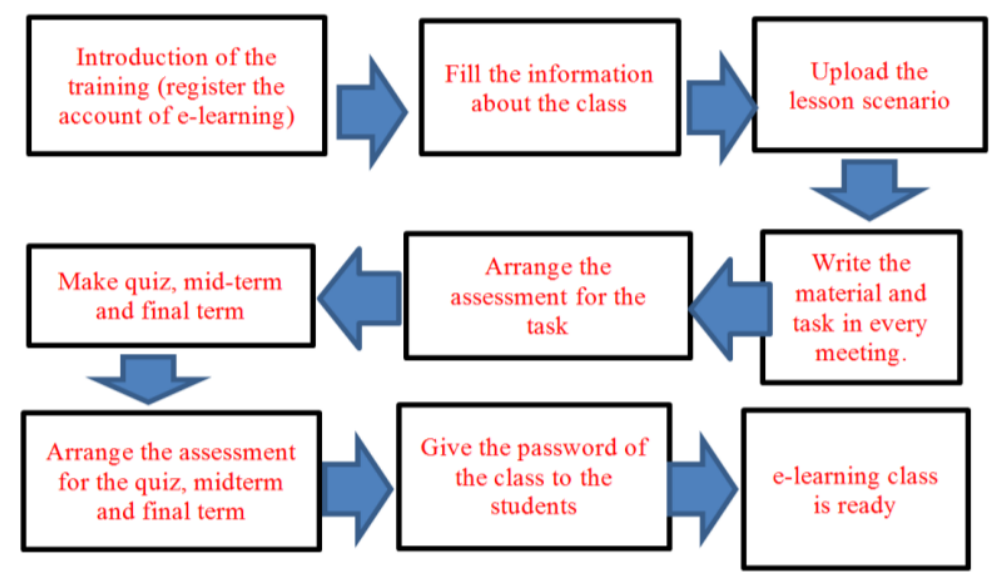

Fig. 2. The steps of E-learning 

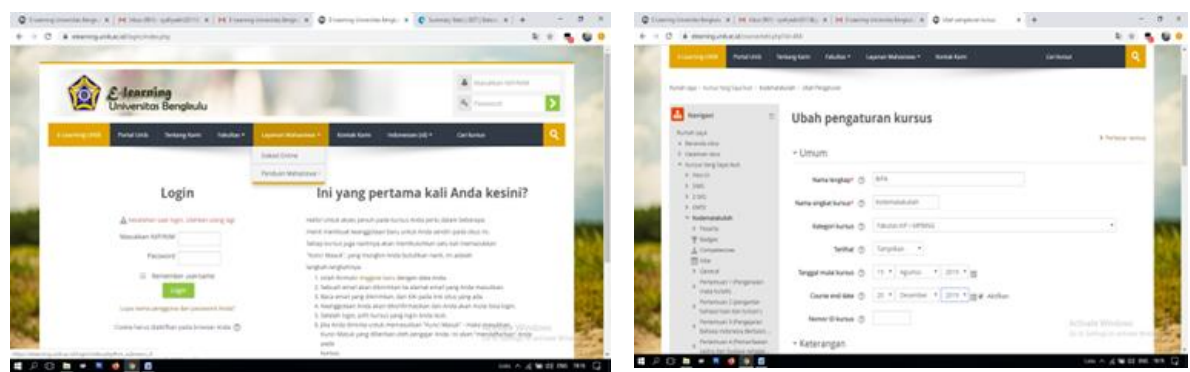

Fig. 3. Registration Process and class information

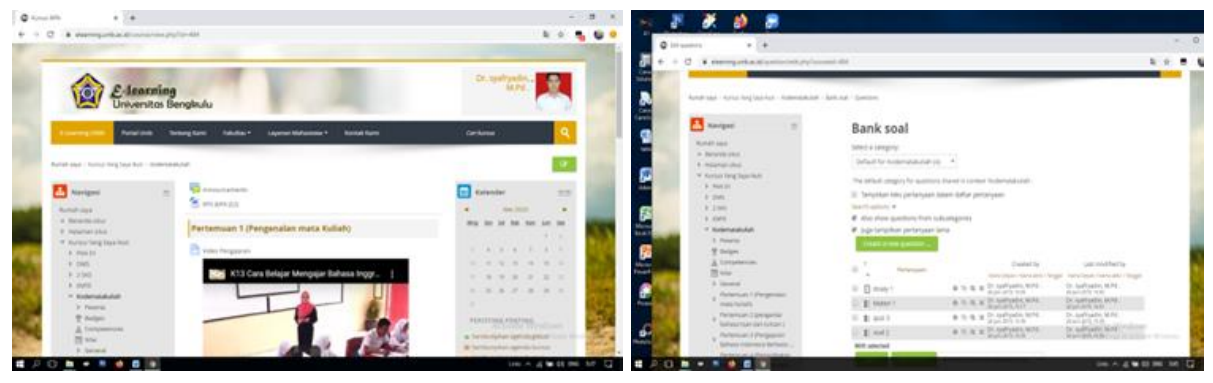

Fig. 4. Upload lesson scenario (RPS) and fill activities every meeting, making Quiz, mid-test and final test

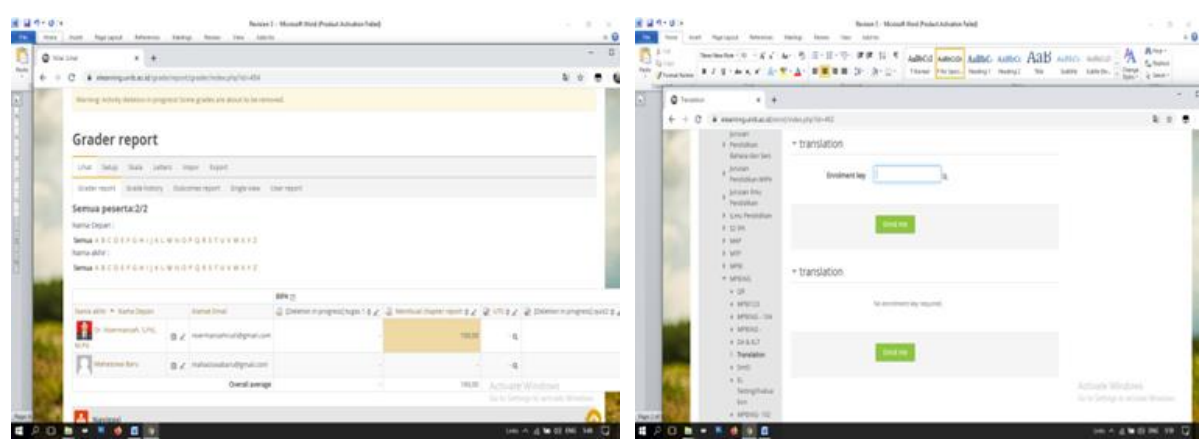

Fig. 5. Assessment and Give enrolment key for students to enter e-learning class

The process of e-learning training was based on the observation checklist and notetaking. In the trainer's observation checklist, all items were done by the trainer from the beginning until the end. The participants were also enthusiastic about joining the training. During the first part in the observation checklist, the trainer elaborated on the 
learning goals, gave apperception to the participants, and obtained information about the level of participants' understanding related to e-learning training. This item was explained by the trainer to them, even though several senior lecturers found it hard to follow the instruction of the trainer. As the second item, the trainer explained the steps or procedures in the e-learning training, which was in line with the learning goals, the explanation is beneficial for participants, used concrete examples related to the explanation of the e-learning training, and implemented all steps in the e-learning training to students and checked students' understanding. In the next item, the trainer provided a good atmosphere in training, guided participants to understand the concept of the material and provided the participants with a chance of asking questions, where the trainer has done it, but in terms of asking questions, many participants asked the same questions because participants came not at same times, thus, the trainer was too tired to answer the questions. During the next item of the observation, the trainer summed up the materials and gave feedback to the students. Furthermore, the item covered the assessment and evaluation of the training. The trainer has done it, but it was a prolonged process because the trainer had to wait for the participants to fill the questionnaire. The last item was managing time. In time management, the trainer has come on time, but several participants did not come on time even though some participants participated at the training.

Based on the observation checklist for participants, there were several items such as participants' enthusiasm, students' interaction and concluding. The first item consisted of ready to join e-learning training, pay attention to the trainer explanation or presentation, manage them comfortably without making noise and prepare book and utensils needed to write down the important materials during the training. In this item, several participants did not bring books or notes in the first and the second meeting. Besides, during the training, some participants were noisy because they talked to other participants which did not have a relation to the training. However, after the next meeting, there were less issues. The second item was comprised of asking the trainer a question related to e-learning implementation. In this part, many participants asked the question from the trainer. In the last item, it consisted of summarizing the important aspects/ sections of e-learning training. In this item, two or three participants did not summarize e-learning training materials because they could copy from other participants' notes.

In short, the process of implementation of e-learning training for lecturers ran well even though there were some issues which could be minimized by the trainer.

\subsection{The lecturers' perspective toward the implementation of the e-learning training}

Based on the interview with some postgraduate lecturers, most of them gave a positive response towards the implementation of e-learning training. Here are samples of the interview transcript as follows: 


\section{Sample 1}

A: What do you think about e-learning training?

Participant 1: eee I think, this e-learning is useful for us especially for me because it is gonna help us as a lecturer to teach. Besides, this training trains me to be familiar with the technology in teaching and learning process.

Participant 2: e-learning training is the first time for me, so this training means a lot for me because I got new knowledge and it can be implemented to my teaching

Participant 3: I think this training made me learn a lot, but because of time duration is not enough and many senior lecturers always asked for repeating the instruction, so it took a lot of time.

Regarding to Sample 1, the answer of the participants showed positive comment. It was proved by sentence "......me because it is gonna help us....". "this training means a lot for me because I got new knowledge...." Besides, this sample 1 indicated that this e-learning is very useful. However, the third participant gave positive and negative comment because he complained about the time.

\section{Sample 2}

A: How did you feel after joining this e-learning training?

Participant 1: Ifeel happy and enjoy because this training is so challenging and fun Participant 2: I am so excited to join this training.

Participant 3: I felt okay to join this training, but several things had to be improved, such as time and the number of trainer.

Based on sample 2, it also showed that this training got good response from participants because it was proved by the statements, "I feel happy and enjoy..." \& "I am so excited". Thus, this training made them joyful, even though there was a problem.

\section{Sample 3}

A: Do you think that this training is okay for you?

Participant1: Yes of course. It is good for me

Participant2: Sure. But may be many things to be improved

Participant3: Not bad.

Based on sample 3, it can be indicated that participants showed their agreement about this training. It means that training gave positive vibes for their development. This can be seen in the answers of the participants, such as "Yes of course. It is good for me", "Sure. But may be many things to be improved", "Not bad". The answer of the participant 2 and 3 seemed to display their suggestion for this training.

\section{Sample 4}

A: Why do you think that this training gives positive impact on you?

Participant 1: ehmmm because this training makes me learn a lot about e-learning

Participant 2: Yeahhh....because I think this training adds my competence in teaching

Participant 3: This training has a good output. To be honest, I never implement elearning like this in my classroom. Thus, this is something not bad and this is new for me.

Regarding sample 4, those utterances have pointed out that the training gave positive vibes for the participants. This can be proved by a quick reading through the answers of participants in sample 4, such as "ehmmm because this training makes me learn a lot 
about e-learning, Yeahhh....because I think this training adds my competence in teaching....". Therefore, it can be said that this training was beneficial for the participants.

\subsection{The barriers of the implementation of the e-learning training and its solution}

The barriers of the implementation of e-learning training: The data of problems in the implementation of the training were derived from the observation checklist and interview. Based on the observation checklist, participants were late to come to the training, so the trainer was tired to repeat the explanation. Besides, most of the participants were senior lecturers that were over 50 , so it was difficult for them to understand the instruction. Next, there was a problem with light. In this case, while the participants were practicing, the light went out, thus the participants had to wait until the light was back on. Another problem was that the participants hardly took notes of the trainers' explanation or instruction of e-learning; consequently, the participants asked questions that had been previously elaborated on by the trainer. Furthermore, the participants also talked to another participant while the trainer was explaining the materials, so the participants did not understand the e-learning material.

Based on the interview of the trainer and the participants, the problems can be seen in the interview transcript in sample 5 and 6.

Sample 5 Transcript of trainer's interview

A: Did you have a problem during you implement the e-learning training?

Trainer: Yes, of course.

A: Tell me about your problems1!

Trainer: The problems are the participants not on time in attending the training because they had another business, such as teaching and meeting. The senior lecturers were hard to teach because they must be guided individually.

Sample 6. Interview transcript of participants' interview

A: What are the problems that you face during the e-learning training?

Participant 1: I think the problems that I faced are difficult to memorize all the instruction of the e learning application because I am never to use e-learning in my class.

Participant 2: hmmmmm....eee I have the problems in terms of the time because during this implementation, I have another meeting in my study program so, I always came late to this training.

Participant 3: The problems that I experience during the implementation of this training are the trainer talked so fast, there was no module for the training, and I seldom to repeat the material at home. Hmmm.. and internet connection also becomes the problem because I got the trouble about it.

Sample 5 and 6 indicate that the problems, which took place during the implementation of e-learning training, were divided into three categories, namely time, understanding of the material, and the module. Here, time is an issue because, in the transcript, there was a sentence "the participants not on time.....", "I have the problems in terms of the time". Then, the issue in understanding the material because, in the 
transcript, the participant said "I seldom to repeat the material at home and "I faced are difficult to memorize all the instruction.....". Another hurdle is the module, given that the trainer did not provide the module in the training and the slow internet connection. This is proved by the participant saying in the interview that there was no module for the training, and I seldom to repeat the material at home ........". In short, the problems were not only experienced by the trainer but also by the participants.

The solution of the e-learning implementation's problems: The solution of the elearning problems can be seen in the interview transcript of the trainer and note-taking during the implementation of e-learning in sample 5.

\section{Sample 7}

The interview transcript of the trainer

A: What is the solution that you give to the participants related to the problems?

Trainer: I handle this problems by asking for my assistant to help me in guiding the participants if they are late to come to my class and they could not follow my instruction. Besides, I also repeat my material, so the participants could understand. I did not give them module because I provide it in soft file.

\section{Sample 8}

A: Are the solutions that the trainer recommends to solve the problems suitable or not?

Participant 1: Yes, of course. It worked, but for the module, the trainer did not give us the hardcopy, because for senior lecturer is hard to read in hand phone or computer.

Participant 2: That is true. The solutions are okay. But I think the assistant must be 2 people not only one because many senior lecturers need a hand to handle their computers.

Participant 3: Yes. I think it is okay, but the module must be given in hardcopy and based on the training.

Sample 8 is one of the confirmations about the solution that the trainer used in the classroom. Those participants said "yes" to the solutions. However, the participants criticized the solutions because the trainer was not all out in giving the solution, such as the module being provided in soft file and the number of an assistant. Those can be proved by looking at the answers of the participants, like "the trainer did not give us the hardcopy, because for senior lecturer is hard to read in hand phone or computer", "But I think the assistant must be 2 people not only one......", and "....the module must be given in hardcopy.....". In short, these critics must be followed up by the trainer.

Based on the note-taking and the interview, the problems can be solved by providing an assistant who can train during the implementation of e-learning because the trainer assistant could help the trainer in teaching the participants about e-learning. Besides, the assistant could offer to help the participants if they felt behind the steps of doing elearning. The statement can be proved by the interview transcript in sample 5 such as, "I handle this problems by asking for my assistant to help me in guiding the participants if they are late to come....". Thus, the problems could be minimized by the trainer. As for the critics toward the solution, the trainer could do the best in the next training. 


\section{Discussion}

E-learning training is essential for postgraduate lecturers, especially for the lecturers of the Postgraduate English Education study program. The discussion is divided into three parts based on the research objectives, namely: e-learning training implementation, for lecturers, participants' perspective towards the implementation of e-learning, and the problems and its solution.

First, e-learning training can be applied to postgraduate lecturers. The implementation of this training can be undertaken in a good way, given that this training is beneficial for the postgraduate lecturers. The training can assist participants in teaching all subjects not only English. This e-learning has also become media for the lecturers, so they did not need to be a central person in the classroom; they played the role of a facilitator. The lecturers just uploaded the materials in e-learning for the students to see it. As Mason and Frank (2009) defined it, e-learning is media for the educator to teach. By using e-learning, the lecturer could easily engage in the teaching and learning process.

The e-learning training took four days because the previous planning was only two or three days, but the postgraduate lecturers thought that two days or three days were not enough. Hence, the training was extended to four days. During the implementation, training had been well done by the trainer, but there were several shortcomings of this training. For example, the process of this training took time because many postgraduate lecturers found it difficult to follow the instructions of the trainer.

Second, most of the postgraduate lecturers gave a positive attitude and response toward the implementation of this training because this training could incline their ability in using information communication and technology in the teaching and learning process. As one of the participants said that "e-learning is useful for us especially for me because it is gonna help us as a lecturer to teach". This utterance means this training gave good impact on the participants. As [7], [8], [9], [10] and [11] who researched on the perception or belief of using ICT either from the students' view or teachers' view. The results of those studies showed that the students and the teachers had a positive response toward the ICT utilization. Here, e-learning is one of ICT utilization in the teaching and learning process. Those studies have shown the results that students had positive feelings, thinking, and an effect on e-learning. This good perception can be proof for the lecturers or teachers to apply e-learning as one of their media for helping the students to learn. Thus, the students could enhance their ability in learning. This statement is supported by [25] and [6] who explained that e-learning correlated with the students' academic achievement. Besides, the students could increase their academic achievement by using e-learning or ICT. ICT could result in good progress for the students in all aspects of learning [22] \& [35]. However, there was a participant who gave a critical statement in a good way. The participants stated that "I felt okay to join this training, but several things had to be improved, such as time and the number of trainers". The sentence sounded good critics to the trainer, but overall, many participants felt happy to join this training.

Third, e-learning training had several problems during its implementation. The problems were that the participants did not come on time, with others not even joining 
the training. This problem was caused by most of the postgraduate lecturers having a meeting at the same time. Besides, the lecturers did not know the information about the training. Consequently, the participants did not know how to use e-learning in the classroom. This problem could be anticipated by giving them extra lessons and extra guidance at another time. If the people were late to come for the training, the trainer provided an assistant to help him to guide the late participants. The understanding of the material or instruction of e-learning became the next problem of this training because it was hard for the lecturers to memorize the instruction of the trainer. They did not make notes during the training, so several lecturers always repeated the same questions. The age factor was one of the factors causing the difficulties of the lecturers in remembering the instruction. This problem could be coped with; the trainer had to repeat the instruction and motivate the lecturers to practice at home. Furthermore, the existence of the module had an important role in the training; however, the printed module was not given by the trainer during the implementation of this training. As a result, it influenced the lecturers' understanding of the material. The trainer provided a solution by giving them a soft copy of the module. Last, technical problems, such as electricity, the projector, and the computer remained problematic. To solve this technical problem, the trainer had to ask for help from an electrician on campus.

In brief, the training was complete, but several problems occurred during the implementation of the training. Those issues were quickly addressed by the trainer. Besides, the responses of participants were both positive and-negative, but the majority of the participants gave a positive response. Overall, this training could be useful to add knowledge of postgraduate lecturers and train them to be virtual lecturers, which they could apply to students in postgraduate programs.

\section{Conclusion}

Based on the findings, it can be concluded that the implementation of this e-learning training was successful even though there were several problems, for instance, time management, the module of e-learning, and the difficulties of senior lecturers to follow the steps in doing the training. Besides, most of the lecturers gave positive comments on this training because it enhanced their knowledge and immensely helped them in teaching. The problems that existed in training were time management, understanding of the instruction, the unavailable module, and the technical problems that could be solved by the trainer. As a solution, the trainer provided one assistant to help the trainer in handling the difficulties of the participants to follow the stages in e-learning. Furthermore, the assistant could help the participants who joined late. The late participants were given an extra lesson outside the training. The problem with a module has been anticipated by giving the participants a soft file of the module. However, the soft file module could not be accepted by all the senior lecturers because they were unable to read it on the computer or mobile phone. The trainer had already asked the participants to print the module. The internet connection problem could be optimized by adding the capacity of the internet in campus. 


\section{$7 \quad$ Acknowledgement}

The funding of this research was from the researchers themselves. The researchers give many thanks to the family and other people who supported this research.

\section{$8 \quad$ References}

[1] Goodwyn, A. (2000). English in the Digital Age: Information and Communication Technology (ICT) and the Teaching of English. London and New York: CASELL.

[2] Mason, R \& Rennie, F. (2009). E-Learning: The Key Concepts. London and New York: Routledge Taylor and Francis Group.

[3] Albiladi, W.S \& Alshareef, K.K. (2019). Blended Learning in English Teaching and learning: A review of the Current Literature. Journal of English Language Teaching and Research. Vol. 10 (2). Pp. 232-238. https://doi.org/10.17507/jltr.1002.03

[4] Malik, A., Schrum, C.S., Johri, A. (2019). Use of twitter across education settings: a review of the literature. International Journal of Educational Technology in Higher Education. Pp. 1-22. https://doi.org/10.1186/s41239-019-0166-x

[5] Gunuc, Selim. (2017). Technology Integration in English Language Teaching and Learning. Teaching English for Specific and Academic Purposes. Vol. 5(2). Pp. 349-358.

[6] Majid, A.N. (2011). The Use of Technology in Teaching English: An Attempt to Develop Student-Centered Learning at Telkom Polytechnic. Proceeding Konferensi Nasional ICT-M Politeknik Telkom.

[7] Sangra, A \& Sanmamed, M.G. (2010). The Role of Information and Communication Technologies in Improving Teaching and Learning Processes in Primary and Secondary Schools. Research in Learning Technology. Vol. 18 (3). Pp 207-220. https://doi.org/10.10 80/09687769.2010.529108

[8] Insani, H.N., Suherdi, D., Gustine, G.G. (2018). Undergraduate Students' Perspectives in Using Edmodo as an Educational Social Network. English Reviewe: Journal of English Education. Vol. 6 (2). Pp. 61-68. https://doi.org/10.25134/erjee.v6i2.1254

[9] Salem, N \& Mohammadzadeh, B. (2018). A Study on the Integration of ICT by EFL Teachers in Libya. Eurasia Journal of Mathematics, Science and Technology Education. Vol. 14 (7). Pp. 2787-27801. https://doi.org/10.29333/ejmste/90594

[10] Oktalia, D., Ngadiso, N., Supriyadi, S. (2018). Integrating ICT in English Language Learning: Students' Perception of a State University in Jambi Province. International Journal of Language Teaching and Education. Vol.2 (1). https://doi.org/10.22437/ijolte.v2 $\underline{\mathrm{i} 1.4529}$

[11] Alhamami, M. (2019). Learners' belief about Language-learning abilities in face-toface and online settings. International Journal of Educational Technology in Higher Education. Pp. 1-23. https://doi.org/10.1186/s41239-019-0162-1

[12] Warni, S., Aziz, T.A., \& Febriawan, D. (2018). The use of Technology in English as a Foreign Language Learning outside the Classroom: An Insight into Learner Autonomy.

[13] Al-Maqtri, M.A.T. (2014). How Effective is E-learning in Teaching English? A Case Study. Journal of Education and Human Development. Vol. 3 (2). Pp. 647-669.

[14] El-Seoud, M.S, et al. (2014). E-Learning and Students' Motivation: A Research Study on the Effect of E-Learning on Higher Education. 
[15] Zhu, C \& Wang, K. (2019). MOOC-based flipped learning in higher education: students' participation, experience and learning performance. International Journal of Educational Technology in Higher Education. Pp. 1-18. https://doi.org/10.1186/s41239-019-0163-0

[16] Alkhalaf, S., Drew, S., Alhussain, T. (2012). Assessing the Impact of E-learning Systems on Learners: a Survey Study in the KSA. Procedia: Social and Behavioral Sciences. Vol. 47. Pp. 98-104. https://doi.org/10.1016/j.sbspro.2012.06.620

[17] Li, Z. (2011). Learner's Reflexivity and the Development of an E-learning Community among Students in China. Research in Learning Technology. Vol. 19 (1). Pp 5-17.

[18] Oweis, T.I. (2018). Effects of Using Blended Learning Method on Students' Achievement and Motivation to Learn English in Jordan: A Pilot Case Study. Education Research InternationL. Pp. 1-8. https://doi.org/10.1155/2018/7425924

[19] Mobinizad, M.M. (2018). The Use of Mobile Technology in Learning English Language. Theory and Practice in Language Studies. Vol. 8 (11). Pp. 1-16. https://doi.org/10.17507/tp $\underline{1 \mathrm{~s} .0811 .10}$

[20] Khanom, S. (2018). Application of ICT in English Classroom: A Study of Secondary Schools in Dhaka. Published Thesis. Dhaka: BRAC Institute of Languages (BIL).

[21] Suherdi, D., Ihrom, S.M., and Nurbiyatun, N. (2018). Incorporating Self-Regulated Learning into English Teaching: Early Lessons from the Implementation of SMELT I 4.0 DE in an UPI Senior High Lab School Class. Proceeding of International Conference on Educational Science. Atlantis Press. https://doi.org/10.2991/ices-18.2019.12

[22] Suherdi, D. (2019). Teaching English in the Industry 4.0 and Disruption Era: Early Lessons from the Implementation of SMELT I 4.0 DE in a Senior high lab school class. Indonesian Journal of Applied Linguistics (IJAL). Vol. 9 (1). Pp 66-75. https://doi.org/10.1 7509/ijal.v9i1.16418

[23] Atshak, M., \& Samari, E. (2011). The Effect of Learning by ICT on Educational Advances among the Students of Payam-eNoor University (PNU). Proceeding of International Conference on Education and Educational Psychology. Procedia-Social and Behavioral Sciences. https://doi.org/10.1016/j.sbspro.2011.11.264

[24] Ukamaka, U.U. (2018). Assessment of ICT Usage among Secondary School Computer Studies Teachers and Students in Nsukka Eductaion Zone (NEZ) of Enugu State, Nigeria. International Conference on Education. The College of Education NSukka, Enugu, Nigeria. https://doi.org/10.17501/24246700.2018.4206

[25] Basri, W.S., Alandejani, J.A., and Almadani, F.M. (2018). ICT Adoption Impact on Students' Academic Performance: Evidence from Saudi Universities. HIndawi Education Research International. Vol.1 (3). Pp. 1-9. https://doi.org/10.1155/2018/1240197

[26] Gasaymeh, A. (2018). A Study of Undergraduate Students' Use of Information and Communication Technology (ICT) and the Factors Affecting their Use: A Developing a Country Perspective. EURASIA Journal of Mathematics, Science and Technology Education. Vol. 14 (5). Pp. 1731-1746. https://doi.org/10.29333/ejmste/85118

[27] Oulmaati, K., Ezzahru, S. \& Samadi, K. (2017). The Use of ICT in the Learning Process among the Students of History and Civilization at Abdelmalek Essaadi University, Marocco. International Journal of Scientific Research and Engineering Technology (IJSET). Vol. 8 (2). Pp. 972-979.

[28] Syafryadin, et al. (2019). Digital Storytelling Implementation for Enhancing Students Speaking Ability in Various Text Genres. International Journal of Recent Technology and Engineering (IRTE). 8 (4). 1-6. https://doi.org/10.35940/ijrte.d8002.118419

[29] Isti'anah, A. (2017). The Effect of Blended Learning to the Students' Achievement in Grammar Class. IJEE (Indonesian Journal of English Education). Vol. 4 (1). pp. 16-30. https://doi.org/10.15408/ijee.v4i1.5697 
[30] Pasternak, D. L., Hallman, H. L., Caughlan, S., Renzi, L., Rush, L. S., \& Meineke, H. (2016). Learning and teaching technology in English teacher education: Findings from a national study. Contemporary Issues in Technology \& Teacher Education, 16(1), 373-387.

[31] Heigham, J \& Croker, R.A. (2009). Qualitative Research in Applied Linguistics: A Practical Introduction. UK: Palgrave Macmillan.

[32] Santhi, D.D., Suherdi, D., Musthafa, B. (2019). ICT and Project-Based Learning in a Rural School: an EFLContext. Proceeding of Third International Conference on Sustainable Innovation-Humanity, Education and Social Sciences. Vol. 353. Pp. 29-35. https://doi.org/ $\underline{10.2991 / \text { icosihess-19.2019.5 }}$

[33] Banyen, W., Viriyavejakul, C., Ratanaolarn, T. (2016). A Blended Learning Model for Learning Achievement Enhancement of Thai Undergraduate Students. International Journal of Emerging Technologies in Learning. Vol. 11 (4). https://doi.org/10.3991/ijet. v11i04.5325

[34] Ghavifekr, S., Razak, A.Z., \& Ibrahim,M.S. (2014). Using Computer and ICT Equipment for E-Teaching and E-Learning: Issues and Challenges Facing Teachers. The Eurasia Proceedings of Educational and Social Sciences (EPESS). Vol.1. Page 1-11. ISPRES.

[35] Heryandi, Y., Said, I., \& Herlina, R. (2020). Online Teaching in Writing by Means of Slack Application. Journal of English Education and Teaching. 4(1), 49-68. https://doi.org/ $\underline{10.33369 / \text { jeet.4.1.49-68 }}$

[36] Abramova VS, Boulahnane S. (2019). Exploring the potential of online English websites in teaching English tonon-linguistic major students: Breaking News English as example. Register Journal. 12 (1):1-12. https://doi.org/10.18326/rgt.v12i1.1-12

\section{$9 \quad$ Authors}

Eka Apriani works for Institut Agama Islam Negeri (IAIN) Curup, Indonesia. eka.apriani@iaincurup.ac.id

Syafryadin works at the Universitas Bengkulu, Indonesia. syafryadin@unib.ac.id

Rita Inderawati works for the Universitas Sriwijaya, Indonesia. rita indera wati@fkip.unsri.ac.id

Arin Arianti works for Universitas Veteran Bangun Nusantara Sukoharjo, Indonesia. ariantiarin7@gmail.com

Sakdiah Wati works for Universitas Muhammadiyah Palembang, Indonesia. $\underline{\text { sakdi }}$ ahwati@gmail.com

Ihsan Nul Hakim works for Institut Agama Islam Negeri (IAIN) Curup, Indonesia. sanulhakim1974@gmail.com

Noermanzah is with the University of Bengkulu, Indonesia. noermanzah@unib $\underline{\text { ac.id }}$

Article submitted 2020-03-07. Resubmitted 2020-10-13. Final acceptance 2020-11-02. Final version published as submitted by the authors. 